Special Comment: This Common Inheritance: Green Idealism Versus Tory Pragmatism Author(s): G. Kearns

Source: Journal of Biogeography, Vol. 18, No. 4 (Jul., 1991), pp. 363-370

Published by: Wiley

Stable URL: https://www.jstor.org/stable/2845478

Accessed: 14-01-2020 09:33 UTC

JSTOR is a not-for-profit service that helps scholars, researchers, and students discover, use, and build upon a wide range of content in a trusted digital archive. We use information technology and tools to increase productivity and facilitate new forms of scholarship. For more information about JSTOR, please contact support@jstor.org.

Your use of the JSTOR archive indicates your acceptance of the Terms \& Conditions of Use, available at https://about.jstor.org/terms

Wiley is collaborating with JSTOR to digitize, preserve and extend access to Journal of Biogeography 


\section{This Common Inheritance: Green idealism versus Tory pragmatism}

\section{THE WHITE PAPER: 'THIS COMMON INHERITANCE: BRITAIN'S ENVIRONMENTAL STRATEGY'}

'This Common Inheritance: Britain's Environmental Strategy' (henceforth TCI) is an important document in British politics. It is the first comprehensive inter-departmental review of Britain's environmental policies. It marks the Conservative Party's first real engagement with the agenda of the Green movement. TCI is certainly presented as a major new departure in politics:

There are moments in history when apparently disparate forces or issues come together and take shape. Almost half a century ago that was true of arguments about the welfare state. In the last decade, the case for market economics has emerged, coherent and formidable, as a blueprint for prosperity and a guarantee of freedom. Today, it is the environment that captures headlines and excites public concern (TCI, p. 8).

TCI explores the possibility of a more caring and less strident form of Conservatism and, although it was prepared under Mrs Thatcher's premiership, it may help define Tory ideology post-Thatcher.

We need to examine the terms on which TCI engages with Green issues and explore the ways in which the other fundamental commitments of the Conservative Party shape the way it meets the environmental challenge. Owens (1986, p. 96) has written of "fundamental differences in philosophy between conservatives and more "radical" environmentalists on allocation of resources, property rights, the role of market[s] and the value of collective as opposed to individual action' which mean that "Greening the Tories" is in this sense a contradiction in terms.' If Owens is right, then, we ought to be able to show how these contradictions appear in TCI.

An examination of the 'structures of negotiation' (Kearns, 1984) in proposals for managing the environment is perhaps one area where human geographers in particular may make a contribution to the discussion of green issues within the subject (Simmons, 1990). Simmons (1989, pp. 391-396), for example, has set out some very stimulating speculations about the way society might respond to environmental problems, but these need to be taken further through a consideration of the political context in which they may be pursued. On the other hand, Johnson's (1989) essentialist account of both capitalism and nature and their inherent opposition appears to preclude any examination of specific proposals short of global socialist revolution. It is perhaps more constructive to work from more widely-shared political goals and to document how their pursuit necessarily entails more radical policies if they are to be realized (see Ryle, 1988). In this spirit, we might consider the commitments, contradictions and limitations of the British Government's new environmental strategy. We can look at moral, economic and political aspects of TCI. 


\section{A GREEN TORY MORALITY?}

The possibility for recognizing a clear responsibility for the environment while remaining committed to economic growth is basic to the Conservative Party's thinking on the environment. In this, they have drawn comfort from the whole debate about sustainable development. In doing so, however, they have failed, or so I am going to suggest, to take seriously the moral arguments about development which underpin much of this work.

Work on sustainable development is rooted, first, in the idea of there being a recognizable global interest in ecological questions. Where the Brandt Commission $(1980,1983)$ reported that the countries of the world collectively had an interest in economic recovery and the Palme Commission (International Commission on Disarmament and Security Issues, 1982) documented a global interest in disarmament and world peace, the Brundtland Commission (World Commission on Environment and Development, 1987) reported to the United Nations in Our Common Future (henceforth OCF) that there was a global interest in conservation. If we are, as a matter of inter-generational equity, to bequeath to our successors the potential for a quality of life equal to our own, then, we need to pay attention to the ecological sustainability of existing economic systems.

In one sense, this is nothing new, since the global interest in controlling pollution is set out in many ecodoomwatch works. But works such as Global 2000 (Council on Environmental Quality, 1982) which urged economic restraint in the rich countries to control pollution and reduce global inequality (Council on Environmental Quality, 1981) were not welcome reading for right-of-centre governments committed to freer markets and more rapid growth. The Reagan Government chose to let Global 2000 lie (McCormick, 1989, p. 173).

The second important similarity between the three U.N. commissions I have mentioned is that they have all shown that the global interest they identify is compatible with economic growth in both rich and poor countries. Brandt claimed to show that Keynesian expansion in the North would create markets for the South which in turn would create the demand to justify the expansion in the North. Palme asserted that the arms race was both unnecessary and economically wasteful in both North and South. Now Brundtland suggests that conservation is a global interest which similarly will allow economic growth in both rich and poor countries.

OCF follows the World Conservation Strategy (International Union for the Conservation of Nature, 1980; Dasmann, 1985) in treating conservation not as an end in itself but as a means to an end - the preservation of genetic diversity against the background of changing human needs. Sustainable economic growth, in these terms, implies the preservation of diversity and the potential for future growth. Now, while this approach does not address the 'political forces behind unsustainable practices' (Redclift, 1987, p. 21), it at least recognizes that the transformation of the natural world is intrinsic to economic development, and it offers a yardstick with which we may measure the suitability of alternative development paths. Questions about the relative rates of desirable economic growth in North and South are basically questions about the acceptable distribution of the world's resources between the two. Buchanan (1973) quite correctly made the relationship between environment and resources the starting point for his discussion of the world population problem, and the basis for his contention that restraint in the North would have greater effect on the environment than fertility control in the South, since it would be more conservative of resources. 
The third strand in this new thinking about sustainable development is that it sees poverty in the South as a major cause of environmental deterioration, suggesting with Simon (1981) that people are the ultimate resource, and that '[i]mprovements in education, health and nutrition allow them to better use the resources they command, to stretch them further' (OCF, p. 95). Investments in human resources can, then, become the core of a strategy which emphasizes the importance of economic security to correct environmental management. Putting poor people first, it is argued, will enable them to adopt a longer-term perspective on their use of resources: 'Contrary to popular professional prejudice, there is mounting evidence that when poor people have secure rights and adequate stocks of assets to deal with contingencies, they tend to take a long view, holding on tenaciously to land, protecting and saving trees and seeking to provide for their children' (Chambers, 1988, p. 3). It is economic insecurity which forces poor people to export primary products and cash crops at the expense of meeting subsistence needs and ensuring ecological sustainability.

TCI takes up some of these moral concerns. It notes that people are possessed of an 'intense hope that we can pass on what we value most about our own heritage to our children' (p. 8). It repeats the argument about the compatibility of economic growth and environmental protection in both rich and poor countries. It commits the Government to the principle of sustainable development which 'means handing down to successive generations not only man-made wealth (such as buildings, roads and railways) but also natural wealth, such as clean and adequate water supplies, good arable land, a wealth of wildlife and ample forests' (p. 47). The report catalogues the Government's membership of various bodies promoting sustainable development.

TCI says very little about the relation of economic development to environmental security. It does not commit the Government to easing the access of third world producers to British markets. It does not commit the Government to meeting internationally agreed targets about the share of Gross Domestic Product to be allocated to development aid. It makes no mention of restricting the export of armaments to poor countries. Nothing is said about the 'depressing effect of [food] surpluses on world markets and consequent impact on developing countries' (OCF, p. 122) and, while developing countries are reminded of the need to adopt policies for 'handling expenditure issues, creating conditions which favour overseas investment and the private sector, minimising movements of capital abroad, encouraging exports and dealing with debt' (TCI, p. 47), nothing is said about restricting the play of commercial forces in poor countries in the interest of equity:

In many countries where land is very unequally distributed land reform is a basic requirement. Without it, institutional and policy changes meant to protect the resource base can actually promote inequalities by shutting the poor off from resources and by favouring those with large farms, who are better able to obtain the limited credit and services available (OCF, p. 141).

The global perspective in TCI relates more to the globalization of problems than of responsibilities. The international dimension of the report comes from the observation that 'in a very short time, human activity has become so varied and complex that it is having effects not only at local and national level, but on the whole world itself' (TCI, p. 9). This compromises the Government's professed commitment to inter-generational equity:

We must put a proper value on the natural world: it would be odd to cherish a Constable but not the landscape he depicted. The foundation stone of all the 
policies in this White Paper is our responsibility to future generations to preserve and enhance the environment and our planet (TCI, p. 10).

In fact, and the reference to Constable implicitly concedes as much, the Report defends the local environment as an amenity value (heritage) and expresses worry about economic growth in the poor countries lest it have disastrous consequences for the global environment. Nowhere does the report address questions of international equity. When the report speaks of leaving a decent environment to our descendants, that 'our' is already structured by class, race and gender in ways which define the inheritance in terms of property rather than equity. The possibility of passing to our direct kith and kin an environment which would support a lifestyle similar to our own appears under threat and it is this propertied inheritance which the Report seeks to secure. Our own children's ability to make a living seems to be compromised by global pollution. Our own children's right to enjoy the landscapes of Constable seems to be compromised by the explosion of day-trippers, the factory-farming of the countryside and the general deterioration in the heritage leisure amenity. Here is the intergenerational equity which is the central concern of TCI.

While not wishing to decry the morality of wishing to do well for one's children, a little more equity within generations might be a more noble goal. And there is, of course, so much more to green morality even than equity. The Report never broaches the question of respect for life tout court. There is nothing here on vegetarianism. There is no attempt to ground a moral purpose in the contemplation of our place within the web of nature. Listen instead to all that is implied in the German Green Party's appeal to 'inheritance':

According to their own statements, they [the establishment parties in Bonn] are leading us to a hopeless choice between Harrisburg and Hiroshima. The worldwide ecological crisis worsens from day to day: natural resources become more scarce; chemical waste dumps are subjects of scandal after scandal; whole species of animals are exterminated; entire varieties of plants become extinct; rivers change slowly into sewers; and humans verge on spiritual and intellectual decay in the midst of a mature, industrial, consumer society. It is a dismal inheritance we are imposing on future generations (Spretnak \& Capra, 1985, p. 28).

\section{A GREEN TORY ECONOMICS ?}

When TCI speaks of placing a proper value on the natural world, this value is to be conceived in economic rather than moral terms. Or, to put the most favourable gloss on this reduction, the only reliable way of valuing things in a market economy is by monetizing their worth. Because the market does not work properly in costing positive and negative externalities, our moral valuation and the prevailing price of things does not match. If only it cost polluters something closer to the ethical value we place on the environment to damage it, then, either they would desist, or we could use polluters' payments to clean up the environment as we go along. Such, at least, was the argument of the report which the Department of the Environment commissioned on market-based approaches to environmental regulation (Pearce, Markandya \& Barbier, 1989).

The Government is against regulations which tell individuals and companies what they can and can not do. Instead, it prefers 'working with the grain of the market' and using 'various forms of pollution charges, as well as taxes and other economic instruments, all designed to encourage customers and producers to 
behave in ways which benefit the environment' (TCI, p. 14). In general, the Government believes in the 'polluter pays' principle where an economic sector is taxed to support the work of the independent regulatory body which will police the sector and ensure that any environmental damage is corrected. The Government can only claim, as it does, that this does not amount to a license to pollute since, despite its general remarks, it also contemplates quite extensive regulation. TCI reports that: "Where there are significant risks of damage to the environment, the Government will be prepared to take precautionary action to limit the use of potentially dangerous pollutants even where scientific knowledge is not conclusive, if the balance of likely costs and benefits justifies' (p. 11). And, when looking at Britain's environmental achievements, TCI remarks that 'Britain led the world in smoke control. The Clean Air Acts of 1956 and 1968 have prevented many thousands of premature deaths from bronchial illness and changed our cities for the cleaner and better' (p. 146). The Government is also considering banning the sale of certain fuels in smoke control areas. In these ways, the Government can clearly claim that it is not offering industry a license to pollute, but it can hardly be said to be working with the grain of the market in doing so.

There is nothing essentially free-market about the use of independent regulatory bodies to police pollution. It matters little who owns the enterprise which is doing the polluting when there is an independent regulatory body. Yet TCI suggests otherwise. Speaking of the water industry, it notes that: 'Investment in cleaning up our rivers and beaches was held back for years by constraints on public expenditure under successive Governments. It took the privatization of the water industry to allow the market to help' (p. 14). The newly privatized water companies are being forced to clean up the environment through a combination of EC regulations and the attentions of the new National Rivers Authority: 'The Government has given the NRA wide powers to enable it to be a tough and effective regulator' (TCI, p. 168).

None of these advantages flowed directly from privatization. The Government could have set up the NRA before now. It could have allowed the old water authorities to raise the revenue necessary (through loans and higher charges) for dealing with pollution. In fact, the private sector has hardly come unbidden into this field. First, the Government improved the credit-worthiness of the water companies by wiping out much of their indebtedness. Second, the Government set a pricing structure for the new private water companies which guaranteed revenue growth outstripping inflation with prices reflecting any new EC regulations. These industries are not being exposed to market forces, they are being protected from the market. Nothing, other than the political costs of doing so, prevented the Government from offering the same latitude to the earlier publically-owned water companies. Price regulation, rather than markets, will always be necessary in this field since water provision tends towards a natural monopoly (Kearns, 1987).

There is no intrinsic opposition between markets and planning (Hindess, 1987). All forms of private property require a certain level of collective provision for them to be enjoyed. At the very least, the legal and police systems must define and protect property entitlements and the state must issue and support a national currency and invest in infrastructure such as transport. There are, however, particular sets of circumstances where markets fail to deliver either efficiency or equity. Where people's initial property entitlements are widely different, as they are in Britain today (Townsend, 1979), markets will probably reinforce that inequality since the desperation of the poor to acquire basic goods gives owners of capital a very powerful weapon which is in no way reciprocal (Roemer, 1988; 
Baker, 1987). Furthermore, where uncosted externalities, natural monopolies and imperfect information prevail, as they do in the case of many environmental questions, markets can hardly be relied upon for efficiency and equity.

TCI argues that externalities will only be fully costed when all the crucial elements are in private hands, for then there is a clear propertied interest which will defend the environment. Consequently, the Report claims that 'Privatization is an important force serving to promote market transparency' (p. 273). Yet private enterprise is interested in short-term profits, and thus has only a weak interest in long-term ecological sustainability. Only regulation of the terms of the lease of resources to private capital could ensure a long-term perspective is taken but again that is to sell the pass on the market itself policing resource use.

Natural monopolies result from the level and inflexibility of capital investment in any environmental services, such as water supply, sewerage, etc. Without regulation, these become merely an occasion to print money through soaraway prices. People desperately need these services and generally have only one possible supply. Not privatization, but regulation, is needed to protect the consumer here.

Environmental information is not widely disseminated and is frequently produced and owned by the very groups wanting to engage in polluting activities. As Bowers (1990) has pointed out, at the time of damage, the full implications of many pollutants was not known. Prior investigation (as with medicines), rather than retrospective evaluation, is needed. The individual consumer quite simply does not have the possibility of researching all the products they use each day. Government-sponsored research coupled with strict controls on which materials are licensed for use would go a lot further than eco-labelling, which is the Government's preferred solution (TCI, p. 222).

The fundamental difficulty with the Government's position is that it has an ideological problem with the whole idea of regulation. TCI is shrill in its denunciation of regulation, yet it actually proposes quite a bit of it. However, TCI also promises that the Government will aim to proceed by voluntary agreement at both national and international levels, and that it will do nothing to damage the international competitiveness of British agriculture and industry. For all the fine rhetoric about sustainable development, economic growth will continue along its present tracks until such time as the whole world comes to its collective sense; there is to be no unilateral greenery here. For example, in the long run, the cost of energy must rise if industry is to be encouraged to use it more sparingly, and thus help combat global warming, but:

Long term measures affecting the relative price of energy can only sensibly be taken when competitor countries are prepared to take similar action. Unilateral action by Britain would do little to influence global warming. It would have a damaging impact on activity and employment in the energy-intensive sectors, relative to our competitors, to little purpose. In the immediate future the reduction of inflation is of overriding importance. Given this, and our best estimate of how long it will take to achieve an international consensus, tax or other measures directly raising the relative price of energy outside the transport sector will not be introduced in the next few years (TCI, p. 69).

The voluntary principle and commercial viability come higher on the Government's set of priorities than does meeting the environmental crisis. With these as constraints on the process of giving the environment an economic value, we can be sure that no radical restructuring is contemplated. 


\section{A GREEN TORY POLITICS?}

The same contradiction between the immediate need to manage a competitive economy of the old sort and the long-term goal of environmentally-sound development compromises the Government's conception of what Green politics involves. The German Green Party tells us that 'Our policies are guided by long-term visions of the future and are founded on four basic principles: ecology, social responsibility, grassroots democracy and nonviolence' (Spretnak \& Capra, 1985 , p. 28). We need to think about why these commitments are necessary. Bahro once described the Green political process thus:

In the richest, industrially over-developed countries of the West a fundamental opposition is growing-above all in the diverse forms of the new social movements. It is reacting to the now clearly and markedly self-destructive, outwardly murderous and inwardly suicidal character of our industrial civilization, and to its institutional system which is geared to continuing in the same old way. What makes this opposition fundamental is above all the fact that it throws into question both the material foundation and its counterpart in our basic attitudes which are oriented towards possessions and having. It gives expression to the very obvious truth that we shall only survive if we equip ourselves to live differently than we have up till now. The Greens see themselves as the parliamentary arm of this fundamental opposition movement (Bahro, 1986, p. 11).

Yet, the Conservative Government understands: by ecology, pollution control which does not threaten profits or competitiveness; by social responsibility, the voluntary exercise of choice by informed consumers; by grassroots democracy, voluntary organizations and minimal local government; and by nonviolence, citizen acquiescence in central government's legitimate exercise of a monopoly of force. It is not serious about abolishing armies, combating centralization or empowering citizens against the state.

Even to consider such a political agenda makes the rather obvious point that the Conservative Party, and indeed the Labour Party, are far from being anarchists. No surprise there, but what we must not lose sight of is the fact that their distance from Green politics measures their unwillingness to place the environment at the top of the political agenda. When difficulties arise, the Government's loyalties lie with economic growth. Yet the Green message is that growth of the present kind is what got us into this mess in the first place and, consequently, that more than mere tinkering is required.

There is, however, a clear political agenda in the 'greening' of the Tories. First, the environment is presented as a leisure amenity to be enjoyed by leisured consumers. Second, privatization effectively offloads environmental protection away from the public budget; 'depoliticizing' the environment in some way. Private companies are to be led gently to use tax money and consumer charges to spend more on cleaning up the environment. At least the Government will no longer be seen to be directly responsible for their failures or for the inflation in costs which will inevitably result. Third, the voluntary principles and the championing of consumer sovereignty further depoliticizes the environmental issue. Eco-labelling will give the people the choice. If consumers persist in buying dirty products, then the fault will lie with them. The Government will have passed the buck. Fourth, and behind all this, vested interests will continue to have privileged access to the policy makers in the name of economic growth. Consider, 
for example, the intellectual somersaults required to reconcile motorway building with the Green agenda. TCI reports the Government opposed to letting traffic congestion find its own level (p. 118) while also believing that car ownership is a fundamental right (p. 72), leaving the coast clear for more road building, since the public transport option is hardly considered at all. The road lobby has nothing to fear from the Green Tories.

There is a more immediate political context in which the Conservative Party wants to look green. It needs a new post-Thatcher image. Yet its commitments to industry and agriculture leave it little room for manoeuvre when it wrestles with questions of environmental regulation. In TCI, the Government places its cards on the table and enjoins debate. Geographers, biogeographers and ecologists should take up the challenge.

Department of Geography,

G. KEARNS

University of Liverpool,

P.O. Box 147, Liverpool L69 3BX, U.K.

\section{REFERENCES}

Bahro, R. (1986) Basic positions of the Greens: for an ecological answer to the economic crisis. Bahro, R. Building the Green movement, pp. 11-22. GMP, London. Originally published in German in 1982.

Baker, J. (1987) Arguing for equality. Verso, London.

Bowers, J. (1990) Economics of the environment: the conservationists' response to the Pearce Report. British Association of Nature Conservationists, from L. Chapman, 23 Donnerville Gardens, Admaston, Telford, Shropshire TF5 ODE.

Brandt, W. (1980) North/south: a programme for survival. Pan, London.

Brandt, W. (1983) Common crisis north/south: cooperation for world recovery. Pan, London.

British Parliamentary Papers Cm 1200 (September 1990) This common inheritance: Britain's environmental strategy. HMSO, London.

Buchanan, K. (1973) The white north and the population explosion. Antipode, 5, (3), 7-15.

Chambers, R. (1988) Sustainable rural livelihoods: a key strategy for people, environment and development. Conroy, C. \& Litvinoff, M. (eds) The greening of aid: sustainable livelihoods in practice, pp. 1-17. Earthscan, London.

Dasmann, R.F. (1985) Achieving the sustainable use of species and ecosystems. Landscape Planning, 12, 211-219.

Hindess, B. (1987) Freedom, equality and the market: arguments on social policy. Tavistock, London.

International Commission on Disarmament and Security Issues (1982) Common security: a blueprint for survival. Simon and Schuster, London.

International Union for the Conservation of Nature

(1980) World Conservation Strategy. IUCN, Gland, Switzerland.

Johnston, R.J. (1989) Environmental problems: nature, economy and state. Belhaven, London.

Kearns, G. (1984) Closed space and political practice: structures of negotiation in the work of Halford Mackinder and Frederick Jackson Turner, Environment and Planning D. Society and Space, 2, 23-30.

Kearns, G. (1987) Private enterprise rains O.K.? London and its water supply. London Journal, 12, 180-186.

McCormick, J. (1989) The global environmental movement. Belhaven, London.

Owens, S. (1986) Environmental politics in Britain: new paradigm or placebo? Area, 18, (3), 195-201.

Pearce, D., Markandya, A. \& Barbier, E.B. (1989) Blueprint for a green economy. Earthscan, London.

Redclift, M. (1987) Sustainable developments: exploring the contradictions. Methuen, London.

Roemer, J. (1988) Free to lose: an introduction to Marxist economic philosophy. Radius, London.

Ryle, J. (1988) Ecology and socialism. Radius, London.

Simmons, I. (1989) Changing the face of the earth: culture, environment, history. Basil Blackwell, Oxford.

Simmons, I. (1990) No rush to grow green? Area, 22, (4), 384-387.

Simon, J. (1981) The ultimate resource. Martin Robertson, Oxford.

Spretnak, C. \& Capra, F. (1985) Green politics: the global promise. Paladin, London. Original U.S edition, 1984.

Townsend, P. (1979) Poverty in the United Kingdom. Penguin, Harmondsworth.

World Commission on Environment and Development (1987) Our common future. Oxford University Press. 